\title{
Factor III Inactivation
}

National Cancer Institute

\section{Source}

National Cancer Institute. Factor III Inactivation. NCI Thesaurus. Code C131662.

Presence of inactivating antibodies to tissue factor (factor III) in the blood. 